\title{
ラドン吸入試作装置によるマウス諸臓器中の 抗酸化機能の亢進に関する研究
}

中川慎也, 片岡隆浩, 迫田晃弘, 石森 有*, 花元克巳, 山岡聖典

\author{
岡山大学大学院保健学研究科 \\ 700-8558 岡山県岡山市鹿田町 2-5-1 \\ *独立行政法人 日本原子力研究開発機構人形峠環境技術センター \\ 708-0698 岡山県苫田郡鏡野町上斎原 1550 \\ 2007 年 10 月 29 日 受理
}

\begin{abstract}
ラドン療法の適応症には活性酸素に由来する生活習慣病が多く, その機構の更なる解明が期待さ れている。また, 汎用性があり医学的効果が再現できるラドン吸入装置の構築は意義が大きい。こ のため, 著者らは共同で開発したラドン吸入試作装置を用い, マウス諸藏器中の抗酸化機能の変化 特性を検討した。ラドン吸入試作装置は, 特殊加工したラドン線源を収納したユニットの数量, そ れへの送風量及び湿度などを調節することによりラドン濃度を自在に調整可能にするものである。 この装置によりマウスに $400 \mathrm{~Bq} / \mathrm{m}^{3}$ あるいは $4000 \mathrm{~Bq} / \mathrm{m}^{3}$ のラドンを吸入させた。その結果，脳 ・肺・肝臓・腎臟において, 抗酸化系酵素である SOD とカタラーゼの両活性が増加し, 過酸化脂 質量が減少した。この抗酸化機能の元進により, 本実験条件でのラドン吸入は活性酸素障害の抑制, すなわち，生活習慣病の予防や症状緩和に効果のある可能性が改めて示唆できた。
\end{abstract}

Key Words : new radon exposure device, radon inhalation, antioxidation function, superoxide dismutase, catalase, lipid peroxide, active oxygen, mouse, radon-222

\section{1.はじめに}

放射能泉であるラドン温泉としては三朝（鳥 取県）やバドガスタイン（オーストリア）など が世界的に有名であり, これらはラドン療法施 設としても注目を浴びている。ラドン温泉は, 一般の温泉にある温熱作用や化学的作用などに 加え放射能としてのラドンに由来する作用もあ り, その主な適応症には活性酸素に由来する生 活習慣病が多( ${ }^{1)-6)}$ 。例えば，岡山大学病院附 属三朝医療センターで実施されているラドン療 法の適応症には, 気管支喘息, 変形性関節症, 高血圧症, 糖尿病, 疼痛などがある77。今まで, これら疾病に及ぼすラドンの作用機序を解明す るために様々な研究がなされてきた8)。例えば, ラドン吸入による脈管作動物質などの血液成分 の変化特性について検討した結果, 組織循環,
モルヒネ様鎮痛作用などを示す変化が報告され ている。また，ラドン吸入に伴い生体内に適量 の活性酸素が生じることにより, 生体防御機構 が活性化されるなど何らかのプロセスを経て活 性酸素病の症状緩和に寄与する可能性も示唆さ れている2)。更に，家鬼を用いたラドン吸入実 験からも次の成果が得られている ${ }^{2)-4)}$ 。例えば, 高濃度（13764〜23 $743 \mathrm{~Bq} / \mathrm{L} ）$ の池田ラジウ 厶鉱泉 (島根県) を用い, これを噴霧状にして ウサギに吸入させる実験をした。その結果，皮 下組織の循環が約 16\% 増加することを明らか にしている9)。また，副腎皮質ホルモン分泌の 促進, 外傷を受けた組織の再生, 免疫反応の活 性化, 抗炎症性効果などの効果を示す総説もあ る ${ }^{1)}$ 。更に, ラットにおいて, ラドン $(1 \mathrm{kBq} / \mathrm{L}$, 663 時間）曝露により副腎の束状帯のミトコン ドリア内膜を有意に増加させる報告 ${ }^{10)}$ がある。 
同様に，ラドン $(2.2 \mathrm{MBq} / \mathrm{L} ， 1$ 回 1 時間， 1 日 2 回，6 日間）曝露は，痛みの知覚や中枢神経 での補助伝達物質としての役割を果たすサブス タンス $\mathrm{P}$ やカルシトニン関連ペプチドのよう な神経ペプチドの産生を賦活化するとの報告も

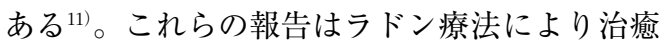
した患者に観察される鎮痛作用や抗炎症作用な どの機構を解明する上で有益な知見となってい る。因みに，高温・多湿がラドン療法に相乗効 果をもたらす一つの因子と考えられている。

ラドンは不活性ガスであり化学的には反応性 がそしいが，脂質に相対的に良く溶ける。主に 肺から吸入され，血流により全身に送られ，脂 肪含有量の多い臓器である内分泌腺や神経繊維 などに取り込まれる。身体中の滞留時間は短 く，1日でほぼ全量が排出される。しかし，こ の短時間にラドンは組織などと接触すると考え られている。また，ラドンは $\alpha$ 線源であり身 体組織内での飛程は約 $20 \mu \mathrm{m}$ であるため, 比 較的大きなエネルギーが組織に対して与えられ る。このため，一連の複雑な有益な刺激作用が 生じる可能性の高いことが示唆されている ${ }^{1)}$

このように，ラドン療法による適応症の症状 緩和の機構について研究がなされているが，そ の明確な作用機序は未だ十分ではない。

他方，放射線などの環境酸化ストレスにより 細胞内に誘導される活性酸素種には，スーパー オキサイドアニオンラジカル $\left(\cdot \mathrm{O}_{2}^{-}\right)$やヒド ロキシルラジカル $(\cdot \mathrm{OH})$ などがある。これ らに対する抗酸化系防御として，スーパーオキ シドジスムターゼ（SOD）やカタラーゼなど の抗酸化物質が備わっている。本研究では，こ れらの酵素活性と，更に酸化の影響度を示す， すなわち, 膜脂質の過酸化の程度を知り得る過 酸化脂質量をそれぞれ指標として検討した。抗 酸化系防御システムのバランスが破綻をきたし 大量の活性酸素が生じたり十分に消去されない でいると, 蛋白質や DNA などの生体構成成分 が損傷を受け，ときに細胞死をもたらす。更に， 組織を構成する細胞の多くが死に至ると，組織
としての機能が損なわれ活性酸素関連疾患とな り得る ${ }^{2), 12)-16) 。 ~}$

他方，ラドンを豊富に含有する温泉は世界に も少なく，地理的にも限定されているのが現状 である。したがって，我々の身近な場所でもラ ドン温泉の生体への有益効果の恩恵を受けるた めに，人工的なラドン温泉が開発されてきた。 通常，人工ラドン温泉では，ラドンを散逸する 粉末状の天然放射性鉱石を貯蔵タンクで温水な どと調製し，その溶液を温泉水として使用して いる。しかし，その放射性鉱石から水中へのラ ドンの溶出率は低いため，水中ラドン濃度を有 益効果の期待できる目標值まで上げ，その濃度 を安定させるのは容易ではない。他方, 線源及 びラドンの濃度を安全基準值以下にして, 健康 に良いとされる最適なラドン濃度まで上昇させ る方法の検討や装置の構築は，ラドンの健康影 響やその作用機序を研究する際においても重要 である。

このため，著者らは既に，当該三朝医療セン ターで実施しているラドン療法とほぼ同様の医 学的効果が再現でき，かつ，汎用性のある小動 物実験用ラドン吸入装置を試作している。

本研究は，ラドン療法の適応症の機構解明に 資するため, 当該試作装置を用い，マウスへの ラドン吸入による医学的効果の程度を知り得る 抗酸化機能の变化特性を検討した。

\section{2. ラドン吸入試作装置の概要・特性}

ラドン吸入装置を試作する上で，ラドン放出 線源の選定がまず重要である。このため, 著者 らはこれまで，天然のラジウム含有鉱石から散 逸したラドンの $\alpha$ 線放出率 (以下, 放出率) とラドンのマウス体内への吸入量について検討 してきた。すなわち，乾燥した後に粉砕した三 朝源泉泥 $(0.400 \mathrm{~Bq} / \mathrm{g})$ を $0.005 \mathrm{~m}^{3}$ の飼育ケ ージに $1969 \mathrm{~g}$ 敷き詰め 40 日間密封し飽和さ せた。その後, $24544 \mathrm{~Bq} / \mathrm{m}^{3}$ の空気中濃度に なったこの飼育ケージに，マウスを 50 分間入 れてラドンを吸入させた後，イメージングプレ 


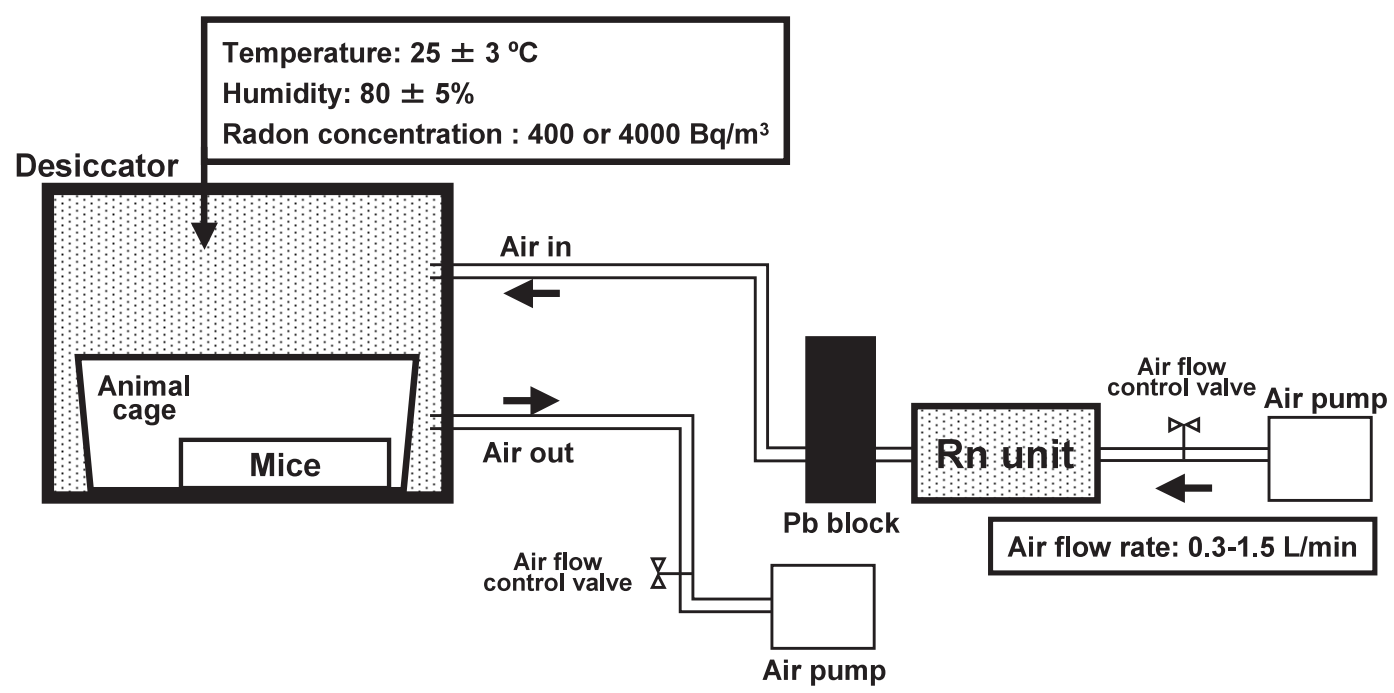

Fig. 1 Schematic diagram of new radon exposure device. The exposure place was set under the above conditions of temperature, relative humidity and radon concentration.

ートを用い測定した。その結果，この吸入条件 では体内のいずれの臓器においても有意なラド ンの残留のないことがわかり, 安全性が確かめ られた

この所見を踏まえ，ラドン線源を特殊加工す ることによりラジウム担持濃度の約 $80 \%$ のラ ドンを発生させる高放出率ラドン線源を(株)尾図 計画（岡山）などと共同により試作した。これ をラドン線源ユニットとした小動物用ラドン吸 入装置を構築した。本装置の概要図を Fig. 1 に示す。ラドン曝露場はデシケーター内（内寸 法：370 mm×260 mm×272 mm)（アズワン(株， 大阪）とし，エアーポンプを用いてラドン線源 ユニットに外気を送風し，この線源ユニット内 のラドンを曝露場へ送った。更に, 曝露場外に 空気を排出した。送風量はSEF-51 (侏)堀場エ ステック，京都）を用いて調節した。マウスの 呼吸量を考慮し, 曝露場内の空気が外気と同等 となるよう，線源ユニットからデシケーターへ の送風及びデシケーターからの排出は $0.3 \mathrm{~L} /$ min 一定に設定した。また，線源ユニットから 放出される極微量の $\gamma$ 線が及ぼす影響を防ぐ ため, 念のため, 鉛ブロックにて遮へいした。 曝露場のラドン濃度は RGD-PS3 (MEASURE
WORKS(株，千葉）を用いて測定した。

本装置における曝露時間に伴うラドン濃度の 変化特性を Fig. 2 に, ラドン飽和後の平均ラ ドン濃度を Table 1 に, それぞれ示す。外気を 相対湿度 $40 \%$ あるいは $80 \%$ に調節し, 線源工 ニットへ, 送風量を $0.3 \sim 1.5 \mathrm{~L} / \mathrm{min}$ に調節し て送った。そして, 線源ユニットから放出され たラドンをシンチレーションセル (Pylon, 300A, カナダ)とそのモニター(Pylon, AB-5, カナダ) により測定した。線源ユニットへの送風量を変 化させた場合, 平均ラドン濃度は, 両相対湿度 とも送風量が高いほど低かった。また, 送風量が $0.3 \mathrm{~L} / \mathrm{min}$ 及び $0.6 \mathrm{~L} / \mathrm{min}$ の場合, 相対湿度 $80 \%$ の方が $40 \%$ に比べ飽和後の平均ラドン濃 度が 1.3 倍高かった。しかし，それ以上の送風 量の場合，相対湿度間で有意な差はなかった。 また，送風量に対するラドン濃度の測定值と理 論值を比較した。

ここで, 線源ユニットからデシケーターへラ ドンが移送される時, デシケーター内の飽和ラ ドン濃度は, 線源ユニットから移送されるラド ン濃度と等しくなる。線源ユニットから移送さ れるラドン濃度の変化は次の微分方程式によっ て表される。 
A

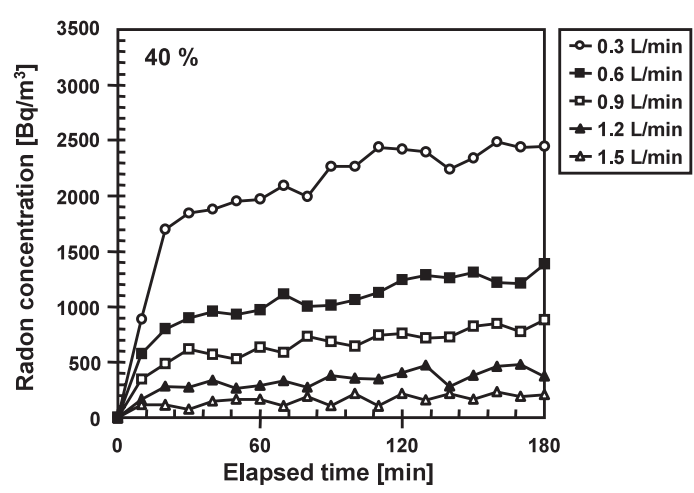

C

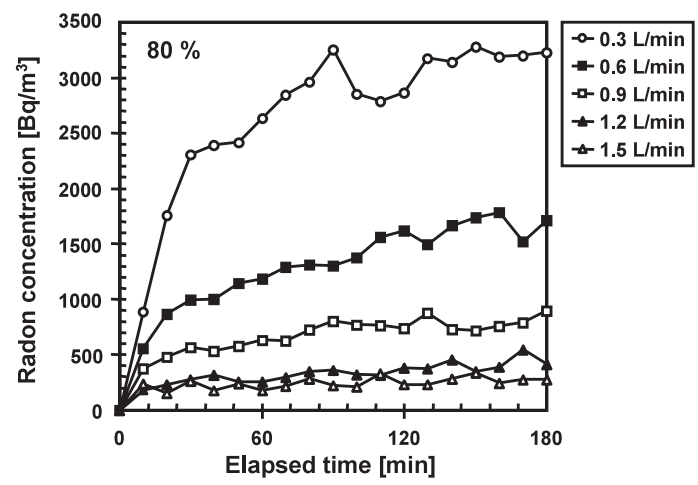

B



D



Fig. 2 Performance evaluation of new radon exposure device.

A : Radon concentration by elapsed time at $40 \%$ relative humidity. B: Difference of theoretical values and measured values on the radon concentration at $40 \%$ relative humidity. C: Radon concentration by elapsed time at $80 \%$ relative humidity. D : Difference of theoretical values and measured values on the radon concentration at $80 \%$ relative humidity.

Table 1 Average radon concentration at each humidity after saturated

\begin{tabular}{ccc}
\hline \multirow{2}{*}{$\begin{array}{c}\text { Flow rate } \\
{[\text { L/min] }}\end{array}$} & \multicolumn{2}{c}{ Radon concentration $\left[\mathrm{Bq} / \mathrm{m}^{3}\right]$} \\
\cline { 2 - 3 } & Relative humidity & $\begin{array}{c}\text { Relative humidity } \\
80 \%\end{array}$ \\
\hline 0.3 & $2501 \pm 101$ & $3129 \pm 110$ \\
0.6 & $1251 \pm 69$ & $1612 \pm 105$ \\
0.9 & $798 \pm 73$ & $835 \pm 90$ \\
1.2 & $401 \pm 28$ & $377 \pm 50$ \\
1.5 & $191 \pm 30$ & $248 \pm 48$ \\
\hline
\end{tabular}

Background: $20 \mathrm{~Bq} / \mathrm{m}^{3}$

$$
\frac{\mathrm{d} C_{\text {out }}}{\mathrm{d} t}=\frac{E+v\left(C_{\text {in }}-C_{\text {out }}\right)}{V}-\lambda C_{\text {out }}
$$

ここで, $C_{\text {out }}\left[\mathrm{Bq} / \mathrm{m}^{3}\right]$ は線源ユニットからデ シケーターへ移送されるラドン濃度, $t[\mathrm{~min}]$ は
経過時間, $E[\mathrm{~Bq} / \mathrm{min}]$ は線源のラドン散逸率, $v\left[\mathrm{~m}^{3} / \mathrm{min}\right]$ は流量, $C_{\mathrm{in}}\left[\mathrm{Bq} / \mathrm{m}^{3}\right]$ は線源ユニッ トへ移送される空気中ラドン濃度 (バックグラ ウンド), $V\left[\mathrm{~m}^{3}\right]$ は線源ユニットの体積, 
$\lambda\left[\mathrm{min}^{-1}\right]$ はラドンの壊変定数である。 これより，定常状態における $C_{\text {out }, \infty}$ は，

$$
C_{\text {out }, \infty}=\frac{E+v C_{\text {in }}}{V \lambda+v}
$$

と表される。

流量 $0.3 \mathrm{~L} / \mathrm{min}$ において飽和ラドン濃度 $C_{\text {saturate, } 0.3}\left[\mathrm{~Bq} / \mathrm{m}^{3}\right]$ が測定で得られた場合, 式 (2)よりラドン散逸率 $E$ が求まる。

$$
E=(V \lambda+v) C_{\text {saturate, } 0.3}-v C_{\text {in }}
$$

式(2), (3)より，その他の流量における飽和 ラドン濃度を計算することができる。

前述の理論值とは，この計算式により算出し た各流量時における飽和ラドン濃度について, 流量 $0.3 \mathrm{~L} / \mathrm{min}$ に打ける飽和ラドン濃度を 1 として規格化した時の值である。

Fig. 2B, D から, 低送風量域では理論值と測 定值は概ね同じであったが, 送風量が高くなる に従い差の生じることがわかった。これより,外 気を高送風量で線源ユニットへ送る際, 曝露場 におけるラドン濃度は期待される濃度より低い 濃度になる可能性があるため, 注意が必要であ る。

本装置で線源ユニット 1 個を用いた場合, 概 ね $3100 \mathrm{~Bq} / \mathrm{m}^{3}$ まで設定可能である。また, 線 源ユニットの数量やこれへの送風量, 送風する 外気の相対湿度を調節することによりラドン濃 度を安全基準值内で自在に調整が可能となった。 これより，ラドン療法で最適濃度となるラドン を効率良く発生させることが可能となった。な お, 本研究で用いたラドン線源は国の安全基準 值（10 Bq/g）以下を遵守しており，放射線管 理区域外でも使用可能である。

\section{3. ラドン吸入試作装置によるマウス諸臓器 中の抗酸化機能の亢進に関する実験}

\section{$3 \cdot 1$ 実験方法}

\section{$3 \cdot 1 \cdot 1$ 実験マウス}

岡山大学自然生命科学研究支援センター・動 物資源部門で空気調整された部屋（気温 $20{ }^{\circ} \mathrm{C}$,
湿度60\%)において, 雄・7〜8週齢(20〜30g) の $\mathrm{BALB} / \mathrm{c}$ マウスを飼育した。飼育期間中, 水及び飭は自由に与えた。また, 本研究は同セ ンター動物実験指針に基づき実施した。

\section{$3 \cdot 1 \cdot 2$ ラドン吸入条件}

ラドン濃度は, 岡山大学病院附属三朝医療セ ンター・ラドン高濃度熱気浴室のラドン濃度 $\left(2650 \mathrm{~Bq} / \mathrm{m}^{3}\right)^{18)}$ を参考に $400 \mathrm{~Bq} / \mathrm{m}^{3}$ あるいは $4000 \mathrm{~Bq} / \mathrm{m}^{3}$ に設定した。また，曝露場内の温 度は $25 \pm 3{ }^{\circ} \mathrm{C}$, 湿度は $80 \pm 5 \%$ に設定した。前 述のラドン吸入試作装置を用い, マウスにラド ンを $8 ， 16 ， 24$ あるいは 48 時間吸入させた。 比較のため, ラドン線源ユニットを除去し, 通 常の空気を吸入させた場合を対照とした。本研 究では， 1 群を 5 匹とした。吸入終了直後に䅡 椎脱臼し，対象臓器を摘出し調製して試料とし， 以下に示す方法に従い測定した。

\section{$3 \cdot 1 \cdot 3$ 抗酸化機能の分析}

SOD 活性の測定は，SOD テストワコー（和 光純薬工業(侏), 大阪）を用い, ニトロブルーテ トラゾリウム（NBT）還元法によった。すな わち, 摘出臓器を $5 \mathrm{mM}$ EDTA-2Naを含む $1 \mathrm{M}$ トリス塩酸緩衝液 (pH 7.4) でホモジナイズし, $12000 \mathrm{rpm}, 45$ 分, $4{ }^{\circ} \mathrm{C}$ で遠心分離し, 上清を 分析濃度に調製し試料とした。更に，この試料 の蛋白質量は比色法で定量し ${ }^{19)}$, 上記で得られ た SOD 活性をこの值で除することにより単位 蛋白質あたりの SOD 比活性を算出した。

カタラーゼ活性の測定は, この酵素が生体内 で生じた $\mathrm{H}_{2} \mathrm{O}_{2}$ を $\mathrm{H}_{2} \mathrm{O}$ と $\mathrm{O}_{2}$ に無毒化すること を利用し, $37{ }^{\circ} \mathrm{C}$ の応溶液中に加えた過酸化 水素の量を波長 $240 \mathrm{~nm}$ の吸光度を指標として 測定し, その減少率からカタラーゼ活性を算出 した ${ }^{20)}$ 。すなわち, 摘出臟器を 5 mM EDTA-2Na

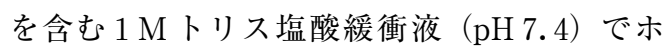
モジナイズし，12000 rpm, 45 分， $4{ }^{\circ} \mathrm{C}$ で遠 心分離し，上清を分析濃度に調製し試料とした。

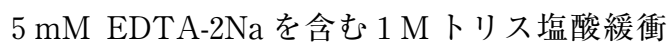
液 $50 \mu \mathrm{L}, 10 \mathrm{mM}$ 過酸化水素を含む $50 \mathrm{mM}$ リ ン酸緩衝液（pH 7.4） $900 \mu \mathrm{L}$, 超純水 $30 \mu \mathrm{L}$, 
そして試料を $20 \mu \mathrm{L}$ 混合し， $37^{\circ} \mathrm{C} に て$ 測定し た。更に，SOD 活性と同様に単位蛋白質あた りのカタラーゼ比活性を算出した。

過酸化脂質量の測定は, 不飽和脂肪酸の過酸 化により生じた分解物，マロンジアルデヒド （MDA）を比色定量することで求めた。測定 には BIOXYTECH LPO-586 Assay Kit (Oxis International, Inc., USA）を用いた。更に，SOD 活性と同様に単位蛋白質あたりの過酸化脂質量 を算出した。

\section{$3 \cdot 1 \cdot 4$ 統計学的処理}

各測定值は，Student's $t$-test によって検定を 行い，関係図中に平均值士標準誤差で示した。
$3 \cdot 2$ 実験結果

$3 \cdot 2 \cdot 1$ ラドン吸入による SOD 活性の変化 特性

脳において，いずれのラドン濃度も吸入 16 時間で有意に増加した。 $400 \mathrm{~Bq} / \mathrm{m}^{3}$ の場合は, 吸入 48 時間でも有意に増加し，対照と比べて も有意に増加を認めた。肺では, $400 \mathrm{~Bq} / \mathrm{m}^{3}$ の 場合, 吸入 24 時間以上で有意に増加した。 4000 $\mathrm{Bq} / \mathrm{m}^{3}$ の場合，いずれの吸入時間においても 有意に増加した。更に，対照と比べ $400 \mathrm{~Bq} / \mathrm{m}^{3}$ では 48 時間で, $4000 \mathrm{~Bq} / \mathrm{m}^{3}$ では 8 時間で有意 に増加した。肝臟では， $400 \mathrm{~Bq} / \mathrm{m}^{3}$ の場合，吸 入 48 時間のみ有意に増加したが， $4000 \mathrm{~Bq} / \mathrm{m}^{3}$ では，吸入前及び対照と比べて，いずれの吸入
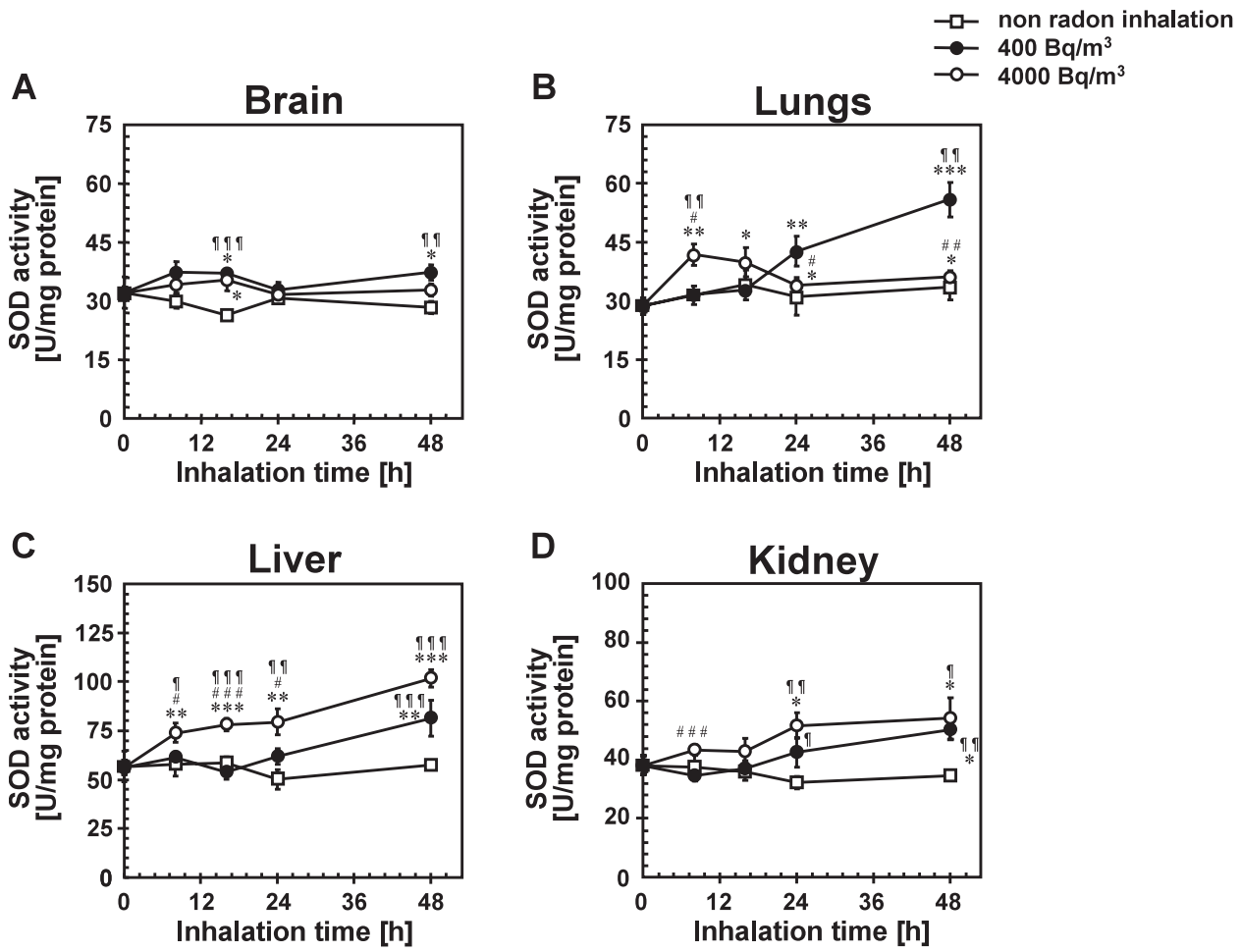

Fig. 3 Time dependent changes in SOD activities in some organs of mice by radon inhalation.

A : Brain, B : Lungs, C : Liver, D : Kidney.

Each value represents the mean \pm standard error of mean (SEM); $\square$ : non radon inhalation, radon concentration $400 \mathrm{~Bq} / \mathrm{m}^{3} ; \bigcirc$ : radon concentration $4000 \mathrm{~Bq} / \mathrm{m}^{3}$. The number of mice per experimental

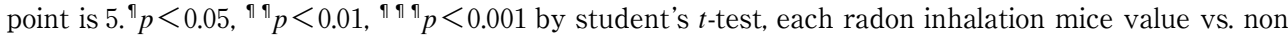
radon inhalation. ${ }^{*} p<0.05,{ }^{* *} p<0.01,{ }^{* * *} p<0.001$, each radon inhalation mice value vs. before radon inhalation. ${ }^{\#} p<0.05$, ${ }^{\#} p<0.01$, \#\# $p<0.001$, each radon inhalation mice value under $4000 \mathrm{~Bq} / \mathrm{m}^{3} \mathrm{vs}$. $400 \mathrm{~Bq} / \mathrm{m}^{3}$. 
時間においても有意に増加した。また，4000 $\mathrm{Bq} / \mathrm{m}^{3}$ の方が $400 \mathrm{~Bq} / \mathrm{m}^{3}$ と比べ吸入 24 時間以 下では有意に高かった。腎臓では, $400 \mathrm{~Bq} / \mathrm{m}^{3}$ では吸入 48 時間のみで, $4000 \mathrm{~Bq} / \mathrm{m}^{3}$ では吸 入 24 時間以上で，それぞれ有意に増加した。 また, $4000 \mathrm{~Bq} / \mathrm{m}^{3}$ の方が $400 \mathrm{~Bq} / \mathrm{m}^{3}$ と比べ吸 入 8 時間では有意に高かった (Fig. 3)。

\section{$3 \cdot 2 \cdot 2$ ラドン吸入によるカタラーゼ活性の} 変化特性

脳において， $400 \mathrm{~Bq} / \mathrm{m}^{3}$ では吸入 48 時間で 有意に増加し, $4000 \mathrm{~Bq} / \mathrm{m}^{3}$ では, 吸入 8 時間 で有意に増加した。また， $4000 \mathrm{~Bq} / \mathrm{m}^{3}$ の方が $400 \mathrm{~Bq} / \mathrm{m}^{3}$ に比べ吸入 8 時間及び 16 時間では 有意に高く, 48 時間では有意に低かった。肺 では, $400 \mathrm{~Bq} / \mathrm{m}^{3}$ の場合, 吸入 16 時間以上で 有意に増加した。 $4000 \mathrm{~Bq} / \mathrm{m}^{3}$ の場合, 吸入 8 時間及び 16 時間において有意に増加した。ま た, $4000 \mathrm{~Bq} / \mathrm{m}^{3}$ の方が $400 \mathrm{~Bq} / \mathrm{m}^{3}$ に比べ吸入 8 時間では有意に高く, 24 時間以上では有意に
低かった。更に, 対照と比べて, $4000 \mathrm{~Bq} / \mathrm{m}^{3}$ での 48 時間を除きいずれにおいても有意に高 かった。肝臟では, $400 \mathrm{~Bq} / \mathrm{m}^{3}$ の場合, 吸入 48 時間のみ有意に増加したが， $4000 \mathrm{~Bq} / \mathrm{m}^{3}$ で は，いずれの吸入時間においても有意に増加し た。また， $4000 \mathrm{~Bq} / \mathrm{m}^{3}$ の方が $400 \mathrm{~Bq} / \mathrm{m}^{3}$ 及び 対照と比べいずれの吸入時間においても有意に 高かった。腎臓では, $400 \mathrm{~Bq} / \mathrm{m}^{3}$ では吸入 48 時間のみ有意に上昇した。 $4000 \mathrm{~Bq} / \mathrm{m}^{3}$ では吸 入 24 時間以上で有意に増加した。また，4000 $\mathrm{Bq} / \mathrm{m}^{3}$ の方が $400 \mathrm{~Bq} / \mathrm{m}^{3}$ と比べ吸入 16 時間を 除き有意に高かった（Fig.4）。

$3 \cdot 2 \cdot 3$ ラドン吸入による過酸化脂質量の変 化特性

脳において, $400 \mathrm{~Bq} / \mathrm{m}^{3}$ では吸入 8 時間及び 16 時間で有意に増加した。 $4000 \mathrm{~Bq} / \mathrm{m}^{3}$ の場合, 吸入 24 時間以上で有意に増加した。また, 4000 $\mathrm{Bq} / \mathrm{m}^{3}$ の方が $400 \mathrm{~Bq} / \mathrm{m}^{3}$ に比べ吸入 16 時間ま では有意に低く, 24 時間以上では有意に高か
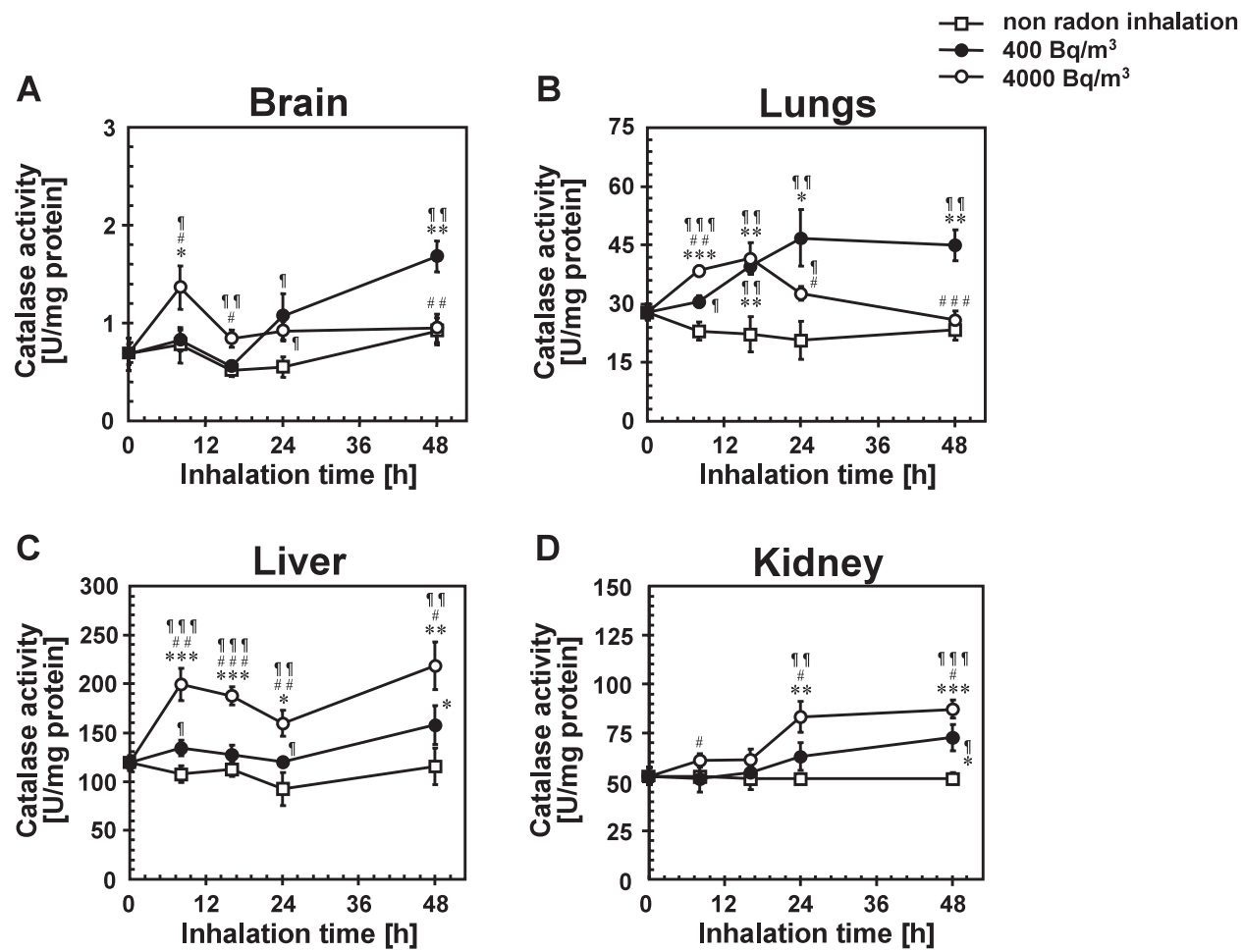

Fig. 4 Time dependent changes in catalase activities in some organs of mice by radon inhalation. The number of mice for each experiment and significance are the same as in Fig.3. 
った。対照と比べて有意に高い值も認めた。肺 では，いずれのラドン濃度も吸入 48 時間のみ 有意に減少した。また, $4000 \mathrm{~Bq} / \mathrm{m}^{3}$ の方が 400 $\mathrm{Bq} / \mathrm{m}^{3}$ に比べ吸入 16 時間のみ有意に低かった。 肝臓では, $400 \mathrm{~Bq} / \mathrm{m}^{3}$ の場合，吸入 24 時間の み有意に減少し， $4000 \mathrm{~Bq} / \mathrm{m}^{3}$ では，吸入 24 時間を除き有意に減少し，対照と比べていずれ の吸入時間でも有意に低かった。また，4000 $\mathrm{Bq} / \mathrm{m}^{3}$ の方が $400 \mathrm{~Bq} / \mathrm{m}^{3}$ と比べ吸入 16 時間の み有意に低かった。腎臟では，いずれのラドン 濃度も吸入 16 時間以上で有意に減少した (Fig. 5)。

\section{$3 \cdot 3$ 考察}

SOD は生体内で生じた反応性の高いラジカ ルである・ $\mathrm{O}_{2}{ }^{-}$を不均化して $\mathrm{H}_{2} \mathrm{O}_{2}$ にする作用を
持つ。また，カタラーゼは肝臓，腎臓等のペル オキシソームに存在し, 組織内で生じた $\mathrm{H}_{2} \mathrm{O}_{2}$ の消去を行い，また，炎症性サイトカインであ る TNF- $\alpha$, IL-1，IL-6 が誘導されることが報 告されている ${ }^{21}$ 。

本研究の結果, ラドン吸入により諸臟器中の SOD とカタラーゼの両活性が増加することが わかった。肺のSOD とカタラーゼの両活性 は, $400 \mathrm{~Bq} / \mathrm{m}^{3}$ のラドンを吸入させた場合，吸 入時間に依存して増加したが， $4000 \mathrm{~Bq} / \mathrm{m}^{3}$ で は 8 時間あるいは 16 時間をピークに低下した。 また，脳も肺とほぼ同様の変化をしたが，その SOD の変化率は小さかった。他方，肝臓と腎 臓では $4000 \mathrm{~Bq} / \mathrm{m}^{3}$ の方が $400 \mathrm{~Bq} / \mathrm{m}^{3}$ に比べ SOD とカタラーゼの両活性がいずれの吸入時 間においても高かった。ここで，ラドンは主に
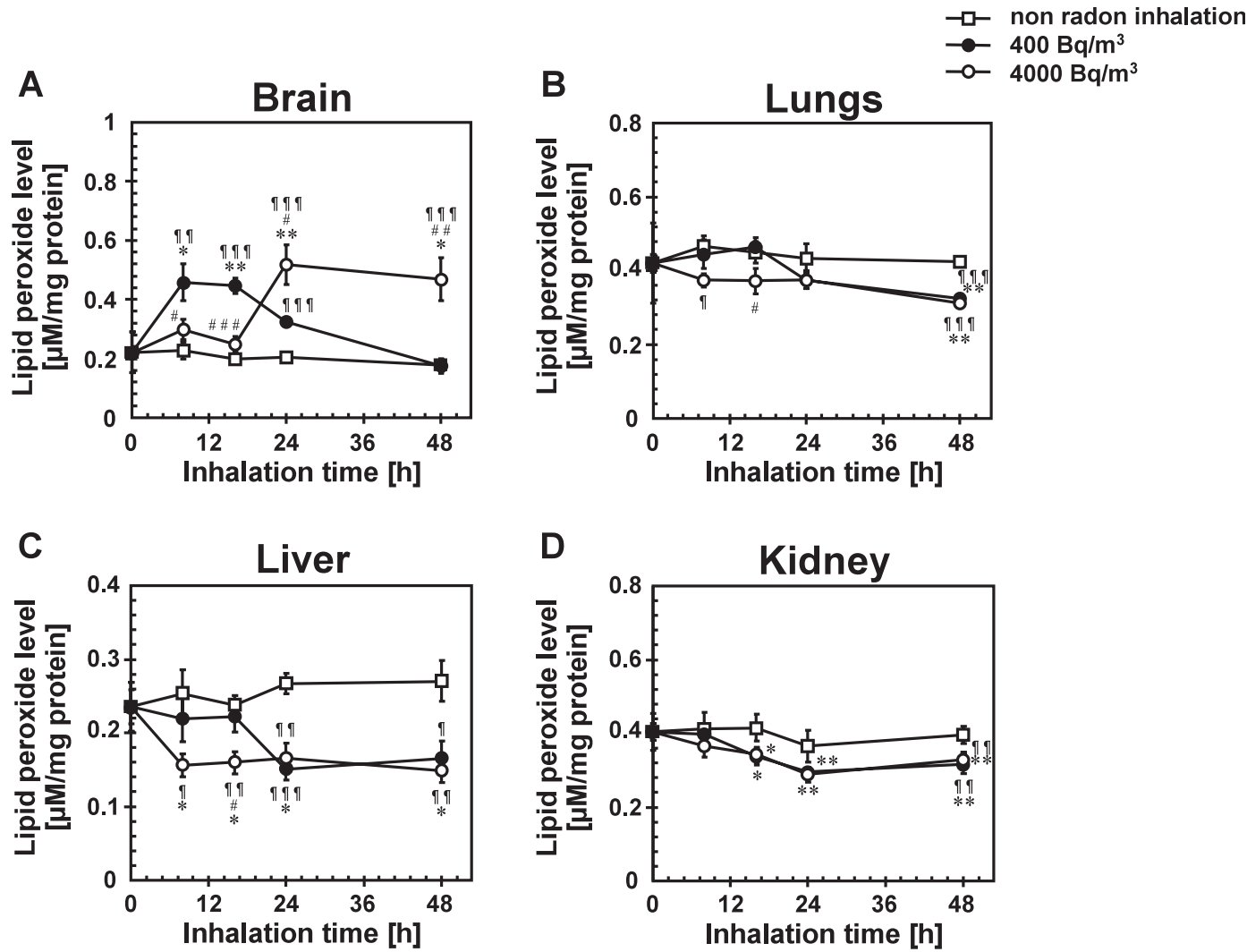

Fig. 5 Time dependent changes in lipid peroxide levels in some organs of mice by radon inhalation. The number of mice for each experiment and significance are the same as in Fig.3. 
肺から吸入され血流により全身に送られる特性 がある1)ため，相対的に高濃度で肺に作用する。 これょり，肺は，他の臟器と比べ低濃度の 400 $\mathrm{Bq} / \mathrm{m}^{3}$ で抗酸化機能が充進したと考えられた。 高濃度の $4000 \mathrm{~Bq} / \mathrm{m}^{3}$ では，立進が吸入時間の 短い時点であった。これは, ラドン吸入量が一 定量に達したため蛋白質である SOD とカタラ 一ゼが誘導合成され，その活性が高くなったと 考えられた。更に, 血液に溶けたラドンは血流 を介して諸臓器へ送られる中, 送血量が多く血 液が早期に送られる脳も, 肺と同様, 低濃度の ラドン吸入により抗酸化機能が立進したが，こ の変化も上述によるものと考えられた。

肝臓と腎蔵のSOD とカタラーゼの両活性は ほぼ同様の変化をしたが, 肝臓の方が腎臓と比 べ変化率は大きかった。これは，ラドンが脂肪 含有量の高い肝臓などの臓器に相対的に集積し 易い特性があり ${ }^{1)}$ ，より刺激作用を受けたため と考えられた。

活性酸素による障害の指標となる過酸化脂質 量は, 肺, 肝臓, 腎臓において, 吸入時間が短 い場合はラドン濃度に依存して, また, 吸入時 間が長くなるほどラドン濃度にかかわらず減少 した。すなわち，ラドン吸入量に依存して活性 酸素由来の障害が軽減されることが示唆できた。 これは, 前述の SOD やカタラーゼの抗酸化系 酵素の活性の増加が原因の一つと考えられた。 このような抗酸化物質の増加と過酸化脂質量の 減少は，X線あるいは $\gamma$ 線の低線量照射実験

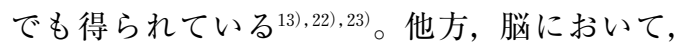
他の臓器と同様, ラドン吸入により抗酸化機能 が立進したが, 両ラドン濃度とも過酸化脂質量 は有意に増加した。これは, 脳中のカタラーゼ 活性が他の臓器に比べ低く, ラドン吸入に伴う 過度の活性酸素に対し十分機能しなかったため と考えられた。しかし， $400 \mathrm{~Bq} / \mathrm{m}^{3}$ で 48 時間 吸入させた場合, 過酸化脂質量は対照レベルま で減少したことから, 結果として抗酸化機能の 克進が誘導され, 活性酸素由来の障害が抑制す ることが示唆できた。

\section{結 論}

本実験条件下でのラドン吸入は, 概ね, 脳と 肺では $400 \mathrm{~Bq} / \mathrm{m}^{3}$, 肝臓と腎臓では $4000 \mathrm{~Bq} /$ $\mathrm{m}^{3}$ において抗酸化機能を六進させることがわ かり, 酸化障害を緩和させる可能性が示唆でき た。しかし, 脳に関しては, 吸入ラドンの濃度 について医学的効果の観点から検討する必要が ある。また, 本研究で検討した諸蔵器において, ラドン感受性は, 脳, 肺, 肝臓, 腎臟の順に高 いことが示唆できた。

\section{謝辞}

ラドン吸入の装置試作については，平成 18 年度財)岡山県産業振興財団「おかやま・チャレ ンジプロジェクト支援事業：天然ラドンミスト 発生装置開発事業」の助成も得て, (株)尾図計画 （岡山）と共同で実施した。特に，同社の尾崎 洋一氏と株ラドン医療研究開発機構（岡山）和 田健一氏には多大な労苦をお掛けしたことに対 し心から謝意を表したい。また，株化研（茨城） の羕沼克嘉氏からも懇切丁寧な技術指導を戴き 深謝する。生化学分析においては, 本学大学院 保健学研究科の水口優子氏, 吉本雅章氏に協力 を戴き感謝する。

\section{文献}

1) Deetjen, P., Epidemiology and biological effects of radon, In Radon in Der Kurmedizin (Pratzel, H. G. and Deetjen, P., eds.), pp.32-38, I.S.M.H., Verlag Geretsried (1997)

2) Yamaoka, K., Komoto, Y., Suzuka, I., Edamatsu, R. and Mori, A., Effects of radon inhalation on biological function-lipid peroxide, SOD activity and membrane fluidity, Arch. Biochem. Biophys., 302, 37-41 (1993)

3) Yamaoka, K., Ishii, K., Ito, T., Komoto, Y., Suzuka, I., Edamatus, R. and Mori, A., Changes in biogenic amine neurotransmitters in rabbits brain by inhalation of radon spring, Neurosciences, $\mathbf{2 0}$, 17-22(1994) 
4) Yamaoka, K. and Komoto, Y., Experimental study of alleviation of hypertation, diabetes and pain by radon inhalation, Physiol. Chem. Phys., 28, 1-5(1996)

5) Yamaoka, K., Mitsunobu, F., Hanamoto, K., Mori, S., Tanizaki, Y. and Sugita, K., Study on biological effects of radon and thermal therapy on osteoarthritis, J. Pain, 5, 20-25(2004)

6) Yamaoka, K., Mitsunobu, F., Hanamoto, K., Mori, S., Tanizaki, Y. and Sugita, K., Biochemical comparison between radon effects and thermal effects on humans in radon hot spring therapy, $J$. Radiat. Res., 45, 83-88 (2004)

7) Evans, W. H. and Graham, J. M., Membrane Structure and Function, Oxford:IRL Press (1989)

8）山岡聖典, 展望ラドン療法の適応症とその機構 解明の現状，Isotope News，588，2-8(2003)

9) Komoto, Y., Kohmoto, T., Nakao, T., Sunakawa, M. and Yorozu, H., Tissue pafusion with radon bath in combination with $\mathrm{CO}_{2}$, Z. Phys. Med. Bal. Med. Klim., 17, 72-78(1988)

10) Pfaller, W., Subzellulare veranderungen der neben-niereneinde nach inhalation von ${ }^{222}$ Radon, Zsch. Baderu. Klimahlkd., 26, 384-390 (1990)

11) Bernatzky, G., Saria, A., Holzleithner, H., Kronberger, C., Wittauer, U., Blum, F., Hacker, G. W., Kullich, W., Leiner, G. and Adam, H., Auswirkungen niedrig dosierter ionisierender strahlung auf regulatorische peptide im blut und in geweben, Z. Phys. Med. Baln. Med. Klein., 19, 36-53(1990)

12) Yamaoka, K., Edamatsu, R. and Mori, A., Increased SOD activity and decreased lipid peroxides levels in rat organs induced by low dose Xirradiation, Free Radic. Boil. Med., 11, 299-306 (1991)

13) Matsuki, O., Nomura, T., Kojima, S., Kubodera, A. and Yamaoka, K., Effect of small-dose gammaray on endogenouse antioxidant enzymes in mice, RADIOISOTOPES, 47, 291-299 (1998) (Japanese)

14) Yamaoka, K., Kojima, S., Takahashi, M., Nomura, T. and Iriyama, K., Change of glutathione peroxi- dase synthesis along with that of superoxide dismutase synthesis in mice spleens after low-dose X-ray irradiation, Biochem. Biophys. Acta, 1381, 265-270 (1998)

15) Kojima, S., Matsuki, O., Nomura, T., Kubodera, A., Honda, Y., Honda, S., Tanooka, H., Wakasugi, H. and Yamaoka, K., Induction of mRNAs for glutathione synthesis-related proteins in mouse liver by low doses of gamma-rays, Biochem. Biophys. Acta, 1381, 312-318(1998)

16) Kojima, S., Matsuki, O., Nomura, T., Shimura, N., Kubodera, A., Yamaoka, K., Tanooka, H., Wakasugi, H., Honda, Y., Honda, S. and Sasaki, T., Localization of glutathione and induction of glutathione synthesis-related proteins in mouse brain by low doses of gamma-rays, Brain. Res., 808, 262-269 (1998)

17）篠塚 龍，マウスにおける温泉由来ラドン族の 体内動態に関する基礎的検討，岡山大学大学院 保健学研究科, 修士論文 (2007)

18）御船政明, 放射能泉と三朝温泉, 温泉科学, 31, 8093(1981)

19) Bradford, M. M., A rapid and sensitive method for the quantitation of microgram quantities of protein utilizing the principle of protein-dye binding, Anal. Biochem., 72, 248-254(1976)

20) Aebi, H., Wyss, S. R., Scherz, B. and Gross, J., Properties of erythrocyie catalase from homozygotes and heterozygotes for Swiss-type acatalasemia, Biochem. Genet., 14, 791-807 (1976)

21) Schonbaum, G. R. and Chance, B., Catalase. The Enzyme, ed., Boyer, P.D., XIII Part C, Chap.7, pp. 363-408, Academic Press (1994)

22) Nomura, T. and Yamaoka, K., Low-dose gammaray irradiation reduces oxidative damage induced by $\mathrm{CCl}_{4}$ in mouse liver, Free Radic. Boil. Med., 27, 1324-1333 (1999)

23) Yamaoka, K., Review : Activation of antioxidant system by low dose radiation and its applicable possibility for treatment of reactive oxygen species related diseases, J. Clin. Biochem. Nutr., 39, 124-143(2006) 


\title{
Abstract
}

\section{Basic Study on Activation of Antioxidation Function in Some Organs of Mice by Radon Inhalation Using New Radon Exposure Device}

\author{
Shinya Nakagawa, Takahiro Kataoka, Akihiro Sakoda, \\ Yuu Ishimori* ${ }^{*}$ Katsumi Hanamoto and Kiyonori Yamaoka \\ Graduate School of Health Sciences, Okayama University \\ 2-5-1 Shikata-cho, Okayama-shi, Okayama Pref. 700-8558, Japan \\ *Ningyo-toge Environmental Engineering Center, Japan Atomic Energy Agency \\ 1550 Kamisaibara, Kagamino-cho, Tomata-gun, Okayama Pref. 708-0698, Japan
}

\begin{abstract}
There are a lot of life style diseases that are related to reactive oxygen species in indications of the radon therapy, and, the further clarification of mechanism is expected. Therefore, in this study, we investigated the activation of antioxidation function in some organs of mice by radon inhalation using the new radon exposure device. It was enable that this device was the adjustments of radon concentration by changing the air flow rate to the specially processed radon source and so on. The mice were made to inhale the radon of $400 \mathrm{~Bq} /$ $\mathrm{m}^{3}$ or $4000 \mathrm{~Bq} / \mathrm{m}^{3}$ with this device. Results show that in brain, lungs, liver, and kidney, both the activities of superoxide dismutase (SOD) and catalase increased, and lipid peroxide levels decreased. This suggests that radon inhalation enhanced the antioxidation function. These findings are important in understanding the mechanism of diseases in which radon therapy is used as treatment, and most of which are called activated oxygen-related diseases.
\end{abstract}

(Received October 29, 2007) 